\title{
Phylogenetic Trees and Other Evolutionary Diagrams in Biology Textbooks and Their Importance in Secondary Science Education
}

\section{Fylogenetické stromy a další evoluční diagramy v učebnicích př́rodopisu a biologie a jejich význam v sekundárním př́rodovědném vzdělávání}

\author{
Markéta Machová ${ }^{1, *}$ \\ ${ }^{1}$ Faculty of Education, Charles University, M. Rettigové 4, 11639 Prague 1, Czech Republic; \\ marketa.machova@student.pedf.cuni.cz
}

\begin{abstract}
Diagrams describing relationship between organisms, and their overall evolution, commonly in the form of phylogenetic trees or other evolutionary diagrams, have become a part of even lower secondary biology textbooks. These diagrams can help promote basic science literacy, yet their design may also strengthen misconceptions about evolution. Therefore, based on the content analysis of 112 Czech biology textbooks for secondary schools (ISCED levels 2 and 3), characteristics of introduced phylogenetic trees and other evolutionary diagrams were recorded and evaluated according to the cladistics to see if their construction supports the current scientific understanding of evolution. The content analysis indicates that the design of nearly half of all diagrams in current lower (ISCED 2) and upper secondary (ISCED 3) textbooks promotes ladder thinking. More than $80 \%$ of all diagrams were not accompanied by instructions on how to read them, meaning that students did not have sufficient scaffolding to understand them. Mainly ISCED 3 textbooks did not introduce additional problem tasks that would support the use of the diagrams in the lessons. Therefore, authors of textbooks should focus more on the construction quality of these diagrams while also supporting their correct application during the educational process. This is likely to prevent a further increase in student misconceptions.
\end{abstract}

Fylogenetické stromy a další evoluční diagramy zobrazující vztahy mezi organismy a jejich evoluci se již staly součástí učebnic biologie a př́rodopisu určených pro sekundární vzdělávání. Tyto diagramy mohou rozvíjet základní př́rodovědnou gramotnost, ale nevhodný způsob jejich zobrazení může také posilovat miskoncepce žáků o evoluci organismů. Ke zhodnocení této problematiky v ČR byla provedena obsahová analýza 112 českých učebnic biologie a přírodopisu pro sekundární vzdělávání (vzdělávací úrovně ISCED 2 a 3). Zaznamenány byly charakteristiky zobrazených fylogenetických stromů a dalších evolučních diagramů a dle kladistiky zhodnoceno, zda jejich stavba podporuje současné vědecké chápání procesu evoluce. Bylo zjištěno, že způsob zobrazení téměř poloviny všech diagramů v učebnicích pro druhý stupeň (ISCED 2) i střední školy (ISCED 3) podporuje tzv. žebříkovité myšlení (ladder thinking). Více než $80 \%$ diagramů neobsahovalo instrukce $\mathrm{k}$ jejich čtení a žáci tak nemají oporu, která by jim umožnila diagramy správně pochopit. Především učebnice pro střední školy neuváděly dodatečné problémové úlohy, které by podporovaly využití těchto digramů ve výuce. Doporučením při tvorbě učebnic je tedy zaměrit se na zkvalitnění konstrukce těchto diagramů a podporu jejich využití ve výuce, což by mělo bránit dalšímu nárůstu žákovských miskoncepcí.

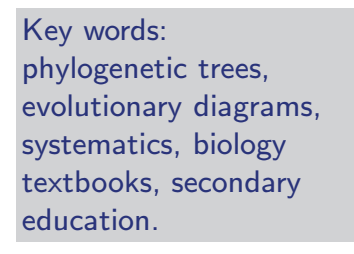

Received 3/2021

Revised 5/2021

Accepted 6/2021

\section{Introduction}

Determination of relations among organisms and their evolution in time are studied nowadays more than ever thanks to the growth of molecular genetics methods (Zrzavý et al., 2004). These findings are then visualised in a form of branching diagrams commonly known as phylogenetic trees (Baum, 2008; McLennan, 2010). And as knowledge of systematics (consisting of both taxonomy and phylogenetics) grew over the last few decades, various phylogenetic trees and other types of evolutionary diagrams found their way even into the lower secondary school textbooks (Catley \& Novick, 2008).

Although these diagrams have the potential to both introduce students to the diversity of organisms on the Earth and their relations as well as promote basic science literacy and a deeper understanding of evolution (Gregory, 2008; Sandvik, 2008), they, unfortunately, showed as problematic. Firstly, they are not self-explanatory and requires instructional scaffolding, and secondly, their design can also reinforce various misconceptions, mainly ladder thinking and inappropriate level of anthropocentrism (Sandvik, 2008). 
These fallacies in understanding the concepts of phylogeny and evolution seem to be rather hard to overcome. Even university students of biology often showed these misconceptions while dealing with the phylogenetic trees (Dees et al., 2014; Halverson et al., 2011; Kummer et al., 2016) - they were unable to correctly interpret the relations between taxa (Phillips et al., 2012; Sa'adah et al., 2017; Sandvik, 2008) and showed a wrong understanding of evolution (Sa'adah et al., 2017). Both biology graduates and undergraduates tended to read the phylogenetic trees from left to right assuming that organisms on the left always show more ancestral traits (Novick et al., 2012; Omland et al., 2008). Even graduates of evolutionary biology and phylogenetics courses struggled to read and build the correct phylogenetic trees (Phillips et al., 2012; Schneider et al., 2012).

This raises the question of whether phylogenetic trees should be even introduced at lower educational levels. On the other hand, the introduction of correctly made phylogenetic trees during the lessons accompanied by instructions on how to understand them can be a tool to challenge students' way of thinking and target their misconceptions about the evolution of organisms (Angielczyk, 2009; Sandvik, 2008). As a special type of diagram, they can be also used to promote not just basic science literacy but also statistical and reading literacy (in other words to promote several key competencies). Therefore, phylogenetic trees can be a very useful part of biology education even at the secondary level if used in the right way.

As evolutionary biology is already introduced at the end of a lower secondary level (ISCED 2), phylogenetic trees can help to visualize its basic principles. This stresses the need to design these trees correctly using cladistic principles. The way the tree is depicted influences how the viewers read and understand it (Dees et al., 2018; Novick et al., 2012), therefore, an inappropriately constructed phylogenetic tree can do more harm than good as it can support the scientifically incorrect ways of thinking mentioned above (Sandvik, 2008).

Unfortunately, only little is known about if biology textbooks help to promote students understanding of phylogenetic trees or if they use them to support the correct concept of evolution and organisms' relations. In the case of Czech ISCED 2 and 3 biology textbooks, there is nothing known about the overall amount or the quality of phylogenetic trees and other evolutionary diagrams as well as their integration into the presented curriculum - neither in the current textbooks nor from a historical perspective.

Therefore, this study aims to explore the following:

- Are basics of phylogenetics and taxonomy (as how relations among organisms are established) introduced in the Czech ISCED 2 and 3 biology textbooks?

- When did the phylogenetic trees and other evolutionary diagrams become a part of Czech ISCED 2 and 3 textbooks?

- What types of phylogenetic trees and other evolutionary diagrams can be found in the Czech textbooks?

- What kind of information do these types of diagrams show (i.e. their characteristics)?

- Does the design of these diagrams support the scientifically correct understanding of evolution (tree thinking)?

- Do the current textbooks contain sufficient scaffolding on how to read and understand these types of diagrams?

\section{Theoretical framework}

Diagrams showing the development and relations between organisms became emblematic visuals of modern biology. Today, these diagrams are commonly grouped under the term phylogenetic tree (or synonymously evolutionary tree) (Reddy, 2011).

\subsection{Brief history of taxa relations determination}

The history of these diagrams began in the second half of the $19^{\text {th }}$ century. At that time, relations among organisms were studied by systematics and their determination relied only on the morphology and anatomy of organisms (Fendrych, 1947; Hoßfeld et al., 2017). The first phylogenetic trees are attributed to Charles Darwin (Gregory, 2008) and were published in his 'On the Origin of Species' in 1859 (Darwin, 1859). In the very next decade, these branching diagrams spread and were used by other scientists (Hoßfeld et al., 2017; Mivart, 1865). 
Progress of genetics during the second half of the $20^{\text {th }}$ century gave rise to the modern phylogenetics that determines relations of organisms according to their heritable traits - not just morphology, but also their DNA (Reddy, 2011; Zrzavý et al., 2004). The shape of phylogenetic trees and methods of their construction then gradually changed - from morphological-based ladder trees such as Haeckel's trees of life (Dayrat, 2003) to a currently popular form of right-angled chronograms based on molecular genetics methods (Omland et al., 2008; Yang \& Rannala, 2012). This resulted in many new findings from major changes in the classification of certain taxonomic groups to the discovery of cryptic species, but it also enabled more precise reconstruction of evolutionary history (Zrzavý et al., 2004).

\subsection{Definition and characteristics of phylogenetic trees}

The term phylogenetic tree is derived from its visual form. Such diagram shows a branching pattern, where every branch represents a certain group of organisms. Branches end up with tips that can represent either higher taxon, a single species or in some cases even a specific gene (Reddy, 2011; Scott \& Baum, 2016). Taxa showed at the tips of the branches are mostly extant, but can be also extinct or represented by fossils (Scott \& Baum, 2016).

Branches divide into nodes that represent speciation events and the last common ancestor of organisms that are represented by the branches descending further from the node (McLennan, 2010); Scott \& Baum, 2016). Therefore, branches can be turned (rotated) at the nodes without a change of diagram's meaning (Fig. 1) (Baum, 2008). This means that it is the topology of branches that really matters and not the order of taxa at the tips of branches (Sandvik, 2008).
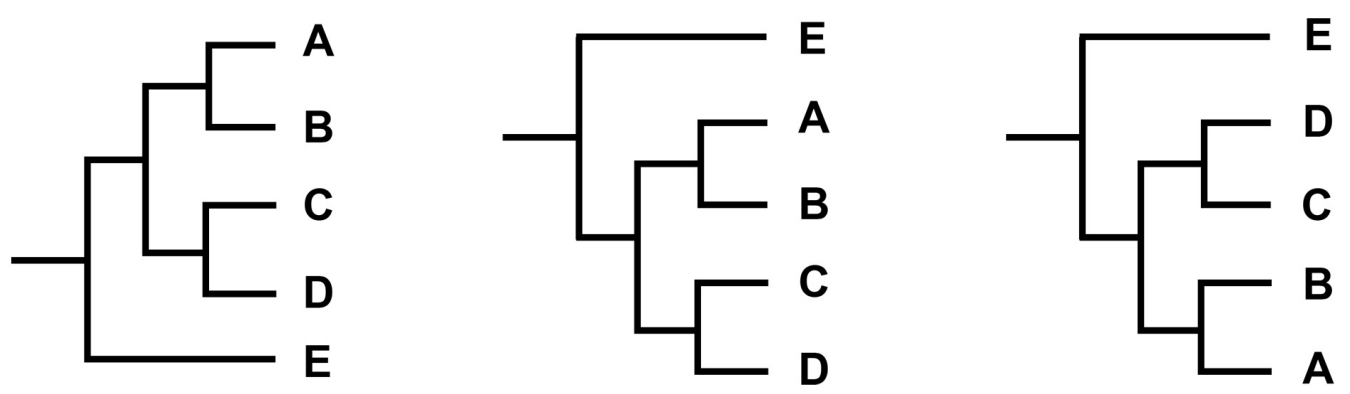

Fig. 1: Three hypothetical phylogenetic trees, each taxon labelled with a letter. All three trees show the same information about the taxa relations, only the branches were rotated in nodes on different levels

In the node, the branch splits into two - if more than two branches are descending from one node, it means that relations among these taxa remain unclear (referred to as polytomy or multifurcation) (Novick \& Catley, 2016).

Phylogenetic trees can be unrooted or rooted, where rooted means that there is one branch representing the last common ancestor of all depicted taxa at the beginning of the tree, and all the other branches are successive to this one (Reddy, 2011; Scott \& Baum, 2016).

To create a branching pattern that is easy to read and visually clear, branches are often connected in $90^{\circ}$ angles. Therefore, every tree can be visualised in several different ways without a change in a branching pattern (McLennan, 2010). Types commonly used in the scientific literature are for example (Baum, 2008) rectangular tree that can be easily transformed into circular or ladder tree (diagonal) (see Fig. 2).
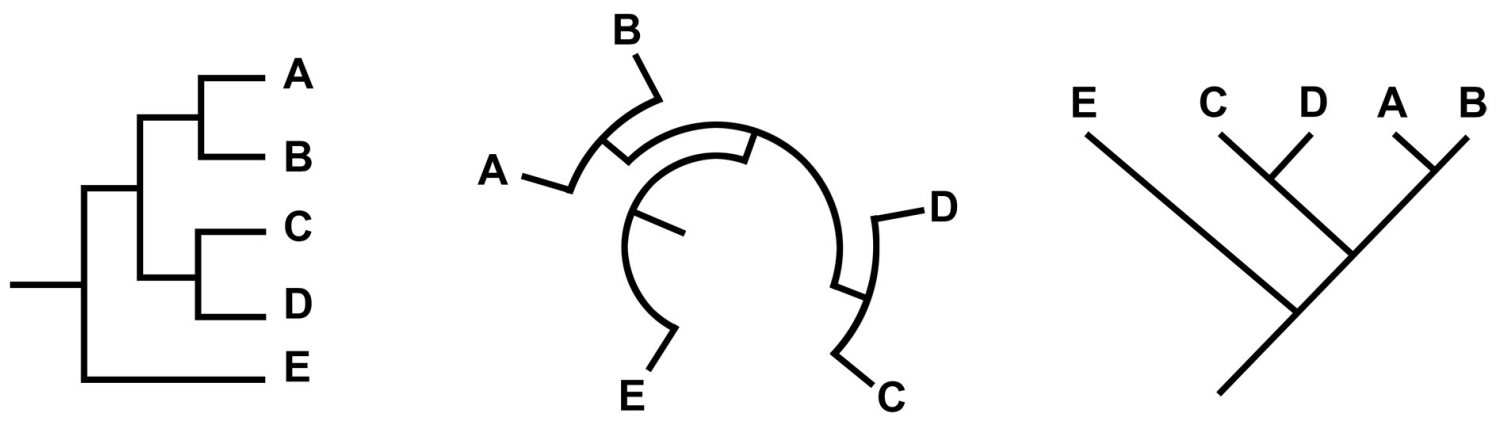

Fig. 2: Three different shapes of the same tree, from the left: rectangular, circular, ladder (diagonal) 
Phylogenetic trees are constructed using various methods, but they all share the common principle organisms are grouped according to their shared unique characteristics (anatomy, morphology, DNA sequence, etc.) (McLennan, 2010; Morrison, 1996). This applies both in the case of analysis of currently living organisms relations as well as relations among extinct and extant taxa (Morrison, 1996). To address these characteristics, it requires specific terminology. Characteristics are described as (McLennan, 2010; Scott \& Baum, 2016):

- plesiomorphy - ancestral state of certain characteristic

- apomorphy - derived state of ancestral characteristic, referred to as a synapomorphy if certain apomorphy is shared within a group of organisms (clade) and as an autapomorphy, if this characteristic is found only in one taxon

Notably, only characteristics of taxa can be assigned as plesiomorphic or apomorphic, not the taxa themselves as they always combine both types of characteristics (Zachos, 2016).

According to the type of represented information, we can divide phylogenetic trees into several categories. In all cases, the hierarchical branching pattern of the tree (broadly referred also as dendrogram) shows the same relations among taxa, but the information given by the branches varies (Podani, 2019; Reddy, 2011; Scott \& Baum, 2016; Zachos, 2016):

- cladogram - shows only relations of taxa through the branching pattern and does not show ancestordescendant relations (extant taxon cannot be ancestral for another extant taxon), represents only relative time (if rooted and consisting of extant taxa, the root represents the past and the tips of the branches present, but nodes themselves do not represent specific points in time)

- phylogram - the length of branches represents the amount of characteristics' change, therefore, the tips of the branches are not equidistant from the root

- chronogram - the length of branches represents the absolute time, and all the tips of the branches are equidistant from the root (in the case they represent extant taxa)

- special types as spindle diagram (also referred to as romerogram, where the thickness of branches represents the diversity of taxa in time) or tree of life (aims to visualise the evolution of life, the root represents the last universal common ancestor of all organisms on Earth)

Till today, various types of phylogenetic trees became ordinarily used at the university level but also found their way into secondary school textbooks (Catley \& Novick, 2008), which requires the ability to read and understand them correctly.

\subsection{Misconceptions in understanding and reading the phylogenetic trees}

The ability to understand and read phylogenetic trees became one of the important goals of biology education (McCullough et al., 2020) as they help students understand not only the relationships among living organisms but also the underlying principles of their origin and processes of evolution (Gregory, 2008; Schramm et al., 2019). Knowledge of relationships among taxa provides deeper insight into their ecology and ethology (Felsenstein, 1985; Wiens, 2004) as well as the process of transmission of infectious diseases and parasites among them (Ypma et al., 2013).

To achieve this understanding among students, it requires to introduce phylogenetic trees constructed according to the cladistics whose design does not promote common misconceptions or rather historical views on the process of evolution (Catley \& Novick, 2008; Dvořáková \& Schierová, 2019) such as ladder thinking and inappropriate level of anthropocentrism.

One of the biggest challenges while teaching the topic of evolution is to shift students understanding from the ladder to the tree thinking (Gregory, 2008). Ladder thinking represents an incorrect historical concept that the development of organisms can be simply depicted by aligning them according to their complexity (Zachos, 2016). Rooted in the concept of scala naturae, it shows evolution as a ladder from the simple unicellular to the more advanced multicellular organisms, often crowned by mankind on the top (Diogo et al., 2015).

Therefore, ladder thinking leads to the wrong assumption that the currently living organisms with the less complex characteristics are ancestors of the more complex or derived ones (Meisel, 2010) or that they are 'less evolved' (Kummer et al., 2016). One of the examples is a common misconception that humans evolved from chimpanzees or that the current unicellular organisms represent the ancestral state of all animals. 
Such visuals (resp. diagrams) are already known by Ernst Haeckel (Dayrat, 2003), but they are not just historical, as they can be found even in current textbooks (Dančák \& Sedlářová, 2011). Even modern cladograms published in scientific journals can imply this no longer valid concept by the arrangement of the organisms at the tips of the branches in left-right or top-down order (or reverse) according to the species richness of presented higher taxa (Zachos, 2016). Scientists themselves then tend to describe extant taxa wrongly as ancestral, while they only carry some ancestral traits (Zachos, 2016).

As the understanding of evolutionary mechanisms deepened, the scientific community shifted towards the current concept of tree thinking. This concept has not been properly defined but revolves around the idea that tree thinking is necessary to successfully extract information about relationships of organisms from phylogenetic trees (Schramm et al., 2019; Scott \& Baum, 2016). The tree thinking skills consist of several main abilities as described by Novick and Catley (2016): understanding how phylogenetic trees depict relations and identifying relatedness of visualized taxa, identifying shared characteristics inherited from the most recent common ancestor (synapomorphies) and using these characteristics to reason about relations, identifying in which order did the new characters arose during the process of evolution, and understanding that rotation of the branches around their nodes does not change the relations of taxa as well as addition or removal of the branches.

Contrary to the ladder thinking, tree thinking promotes the view that all currently living organisms share common ancestors, and, no matter the complexity of their characteristics, they all share the ability to maintain their existence in the current environment and successfully overcame a long time of development that more or less shaped them to their current form (Zachos, 2016). Therefore, it implies that although some extant organisms have more complex characteristics than others, they cannot be perceived as better or higher, neither as having an ancestor-descendant relationship (Diogo et al., 2015; Kummer et al., 2016; Zachos, 2016).

The same applies to mankind. Both scientists and teachers very often face the common idea of strong anthropocentrism, which means positioning man on the top of all the living beings and understanding nature only from the perspective of human life. Humans are often presented as one of the most complex organisms on Earth, but it does not make them implicitly better or way more important than any other organisms they share Earth with. Anthropocentrism is often blamed for various phenomena in science education - as understanding microorganisms more as a cause of diseases than an important part of the ecosystem helping to decompose and cycle the matter (Byrne et al., 2009) or belief that cell death and ecosystem disturbance have always only negative implications (Coley \& Tanner, 2012). Effects of anthropocentric thinking are also often discussed in environmental education while reasoning for environment protection (Cocks \& Simpson, 2015; Kopnina, 2014).

In phylogenetic trees, anthropocentrism is emphasized by aligning the organisms according to their complexity with humans placed in some privileged position (as on the top of the tree or the very right side, as the trees tended to be read from left to right). This is mainly visible when the tree also promotes the ladder thinking and its branches are also not equidistant from the root. Similarly, as in the case of ladder thinking, trees can also end up looking anthropocentric if the taxa are aligned from the ones with the oldest common ancestors to the youngest.

All of these problems can be easily fixed by rotation of branches in their nodes and making all the branches tips with extant taxa equidistant from the root, so the reader focus more on the branching pattern rather than the order of the taxa on the branches tips (Zachos, 2016).

\section{Methods}

To evaluate the amount and the characteristics of all phylogenetic trees and other evolutionary diagrams in Czech science education, content analysis was carried out. It included Czech biology textbooks aimed for educational levels ISCED 2 and 3 and textbooks recommended for ISCED 3 students' final exams ('Maturitní zkouška'). To gain a historical perspective and reveal when the knowledge of systematics and phylogenetic trees were first introduced in the textbooks, all textbooks that were published after the first edition of Charles Darwin's 'On the Origin of Species' (1859) were included.

Textbooks were divided into four groups according to the year of publishing: archaic (published from 1859 to 1917), historical (1918-1948), post-war (published from 1949 to 1989), and currently used (still being available in stores and used by teachers, published after 1990 and later). Chosen periods represent the main events in the development of the Czech educational system, which were the end of the Austrian Empire after the 1848 revolutions, the establishment of the Czechoslovakia, socialist era, and the new development after the Velvet Revolution (Čornejová et al., 2020).

If it was possible to access more than one edition of a single textbook, they were compared. In the case of current textbooks (published after 1990), significant differences among various editions in content 
concerning the topic of systematics (i.e. taxonomy or phylogenetics) were only discussed. Therefore, only the newest editions were used in the content analysis itself. In the case of the textbooks published before 1990, editions with such differences were included in content analysis and counted as two separate books. Different editions of a single textbook that were compared but showed having the same content are cited in Appendix 1 (part $\mathrm{C}$ ).

All textbooks were subjected to the content analysis of topics of phylogenetics and taxonomy, i.e. searched for any information about how are relations among organisms generally established and visualised both in the term of the taxonomic groups or individual species relations. Found content was divided into two categories: explanatory text and visuals (both text-based and diagram with pictures).

Explanatory text was either focused on the taxonomy (as the introduction of binomial nomenclature or Linnean categorization that enables to group related organisms), or phylogenetics in general (explanation of determination of organisms' relationships and phylogenetic trees construction and reading).

Visual (or graphic) elements were subjected to both qualitative and quantitative content analysis. All elements that were describing either taxonomic groups, their relationships, or development in time were included. As textbooks often do not use the same formats of displaying taxa relations as scientific literature does, there was a need to develop a specific categorization system. Therefore, Catley and Novick's (2008) categorization was adopted and partly altered. Four main categories of all textbooks' graphic elements related to taxonomy and phylogenetics were established:

- taxonomic overview - plain list of taxonomic groups with assigned lower subphyla (as classes, orders, families, etc.) without the depiction of their relations, unrooted, showing mainly polytomies

- linear depiction of evolution - organisms' development viewed exclusively as a linear change from one species to another, even though it should be portrayed as cladogenesis and not anagenesis (e.g. famous illustration of ape gradually changing to modern human)

- phylogenetic tree - in this study, this term is narrowed to the diagram constructed according to the basic cladistic principles, i.e.: representing relations among the depicted species without implying ancestor-descendant relations (e. i. species placed only at the tips of the branches), extinct taxa clearly differ from extant (labelled or their branches are visibly shorter), all extant taxa are equidistant from the root (unless it is phylogram), not using polytomies (or only in cases where taxa relations are not yet established); these phylogenetic trees were then divided according to their visual form into three groups (see Fig. 3) according to Catley and Novick (2008):

- tree (rectangular) - branches create a clear levelled structure, could be both bifurcate at the right angle (most common in professional biology journals) or with branches rounded in nodes

- ladder (diagonal) - branches are following one main diagonal line, branches can be rounded at nods

- other types - branching structure does not show distinguished levels and no diagonal line is present
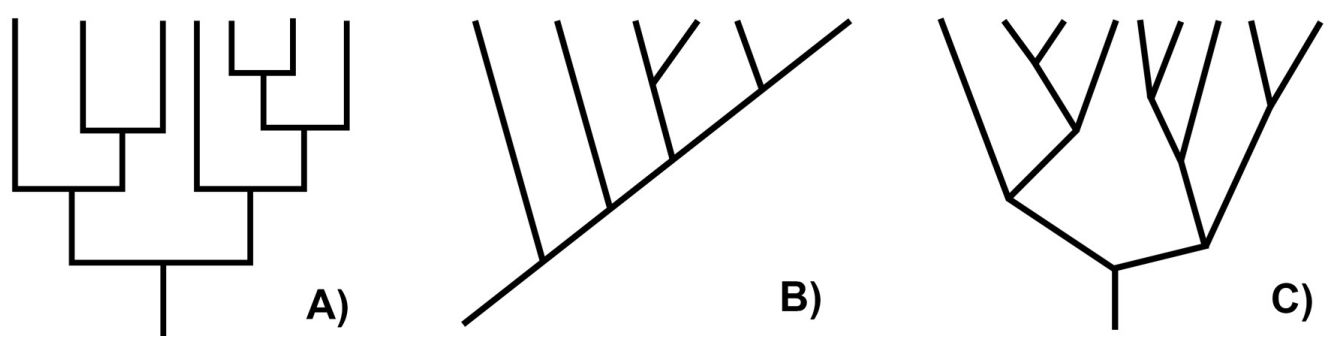

Fig. 3: Illustrations of types of cladograms distinguished in this study, from left: A) - tree cladogram, B) ladder (diagonal) cladogram, C) - other

- other evolutionary diagrams - other established types of phylogenetic trees or any other evolutionary diagrams showing either only development or both development and relations between taxa with deviations from traditional cladistics (e.g. 'ancestry' taxa are placed in the middle of the branches, extant taxa in different distance from the root, depicted as a bar chart, or non-Darwinistic trees of life); these diagrams were further assigned to the several categories established in the scientific literature as:

- Haeckel's tree of life - rooted, length of branches varies and has no meaning, supporting ladder thinking 
- chronogram - branches show relations of the taxa and their length represents time, contains an additional timeline

- spindle diagram - showing an abundance of taxa during the time with or without their relations

- other - diagram bordering the characteristics of types above

Furthermore, several key characteristics of all phylogenetic trees and other evolutionary diagrams found in currently used textbooks were recorded. These characteristics were chosen according to how the diagrams:

- enable the reader to gain information about the introduced taxa, their relations, and their development in time

- influence scientifically correct understanding of evolution (tree thinking)

- resemble the phylogenetic trees commonly used in the scientific literature

Therefore, these characteristics related to the phylogenetic trees and other evolutionary diagrams were recorded:

- anthropocentric - humankind is explicitly placed in the privileged position among other organisms (as on the very right side, on the top, in much bolder colours etc.)

- supporting ladder thinking - organisms are aligned at the tips of the branches according to their complexity in left-right or top-down order or reverse

- polytomy - at least one clearly visible polytomy of the taxa, whose relations were already known by the time of publishing the textbook

- time-respecting - all currently living organisms are equidistant from the root, extinct organisms have visibly shorter branches

- rooted - visible root or marking of the last common ancestor

- right angles in the nodes - branches are connected always at the right angle

- time scale - additional time scale or time markings of important events in time

- hominids evolution - diagram contains the evolution of hominids (only or among other taxa)

- species illustrations - introduced taxa are represented by a picture of a certain specie

- coloured - diagram and the illustrations in it are colourful or only black and white

- instructions - any additional text instructions on how to understand and read the presented diagram, these can be both in the textbook's text or in the diagram's caption (i.e. simplified principles of cladistics and tree thinking), does not mean a description of taxa, branches division or a timeline that is already presented in the diagram

Notably, flaws in relations among taxa (f.e. use of paraphyletic groups) were not recorded as this topic itself is broad and would require a separate study.

\section{Results}

The analysis contained altogether 112 textbooks for ISCED 2 and 3 educational levels with different titles or different content of searched topics, several of them were found in two or more editions (see Tab. 1, whole list available in Appendix 1).

Tab. 1: Number of textbooks subjected to content analysis in all categories according to the year of publishing

\begin{tabular}{lccccc}
\hline \multirow{2}{*}{$\begin{array}{l}\text { Educational } \\
\text { level }\end{array}$} & $\begin{array}{c}\text { archaic } \\
(1859-1917)\end{array}$ & $\begin{array}{c}\text { hear of publishing } \\
(1918-1948)\end{array}$ & $\begin{array}{c}\text { post-war } \\
(1949-1989)\end{array}$ & $\begin{array}{c}\text { current } \\
(1990+)\end{array}$ & $\begin{array}{c}\text { Sum per } \\
\text { level }\end{array}$ \\
\hline ISCED 2 & 3 & 12 & 7 & 39 & 61 \\
\hline ISCED 3 & 10 & 8 & 14 & 19 & 51 \\
\hline
\end{tabular}




\subsection{Phylogenetics and taxonomy in the textbooks}

Explanation of concepts of binominal nomenclature and Linnean categorization and even a short description of phylogenetics as a science were all found already in historical textbooks. In post-war textbooks, description of binominal nomenclature and Linnean categorization were part of half of all the textbooks, while at least simple information about how the relations of taxa are determined according to their similarities was found in $38 \%$ of the cases.

In current textbooks, the introduction of taxonomy as a science, Linnean categorization of taxa and binominal nomenclature were part of at least one textbook from each edition aimed for ISCED level 2 and half of all the textbooks for ISCED level 3.

Phylogenetics, on the other hand, was introduced only in two current textbooks for ISCED level $2-$ very shortly as a science focused on the development of species (Cílek et al., 2000; Pelikánová et al., 2016). Three current ISCED 3 textbooks contained a simplified description of how the relations among taxa are determined and how to understand the phylogenetic trees (Benešová et al., 2013; Kincl et al., 2008; Šmarda, 2003). Two textbooks, containing a full chapter devoted to this topic, were also published during the last decade (Flegr et al., 2017; Rosypal et al., 2003).

\subsection{Types and amount of visual elements related to phylogenetics and taxonomy}

The first published diagram showing relations among taxa was recorded in 1936 (Bartušek, 1936), but

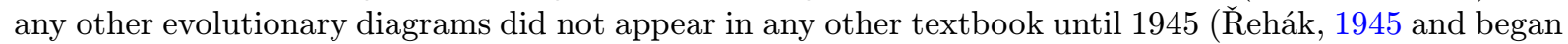
to be more abundant only later during the post-war era (Tab. 2).

Tab. 2: The number of textbooks containing any visual (graphic) elements related to taxonomy and phylogenetics. Total number of textbooks in individual categories: archaic $=13$, historical $=20$, post-war $=21$ and current $=58$. The percentage was counted from the sum of the textbooks in every individual category

\begin{tabular}{|c|c|c|c|c|c|c|c|}
\hline \multirow{3}{*}{$\begin{array}{l}\text { Textbook } \\
\text { category }\end{array}$} & \multicolumn{7}{|c|}{ Type of searched visual element and number of textbooks containing it } \\
\hline & \multirow[t]{2}{*}{ Nothing } & \multirow{2}{*}{$\begin{array}{c}\text { Taxonomic } \\
\text { overview }\end{array}$} & \multirow{2}{*}{$\begin{array}{c}\text { Linear } \\
\text { depiction }\end{array}$} & \multirow{2}{*}{$\begin{array}{c}\text { Evolutionary } \\
\text { diagram }\end{array}$} & \multicolumn{3}{|c|}{ Phylogenetic tree } \\
\hline & & & & & tree & ladder & other \\
\hline Archaic & 6 & 7 & 0 & 0 & 0 & 0 & 0 \\
\hline percentage & $46 \%$ & $54 \%$ & $0 \%$ & $0 \%$ & $0 \%$ & $0 \%$ & $0 \%$ \\
\hline ISCED 2 & 2 & 1 & 0 & 0 & 0 & 0 & 0 \\
\hline$\overline{\text { ISCED } 3}$ & 4 & 6 & 0 & 0 & 0 & 0 & 0 \\
\hline Historical & 10 & 9 & 0 & 3 & 0 & 0 & 0 \\
\hline$\overline{\text { percentage }}$ & $50 \%$ & $45 \%$ & $0 \%$ & $15 \%$ & $0 \%$ & $0 \%$ & $0 \%$ \\
\hline ISCED 2 & 8 & 4 & 0 & 0 & 0 & 0 & 0 \\
\hline$\overline{\mathrm{ISCED}} 3$ & 2 & 5 & 0 & 3 & 0 & 0 & 0 \\
\hline Post-war & 8 & 6 & 1 & 11 & 0 & 0 & 0 \\
\hline percentage & $38 \%$ & $29 \%$ & $5 \%$ & $52 \%$ & $0 \%$ & $0 \%$ & $0 \%$ \\
\hline ISCED 2 & 4 & 1 & 1 & 2 & 0 & 0 & 0 \\
\hline$\overline{\text { ISCED } 3}$ & 4 & 5 & 0 & 9 & 0 & 0 & 0 \\
\hline Current & 15 & 29 & 10 & 17 & 5 & 4 & 4 \\
\hline$\overline{\text { percentage }}$ & $26 \%$ & $50 \%$ & $17 \%$ & $29 \%$ & $9 \%$ & $7 \%$ & $7 \%$ \\
\hline$\overline{\text { ISCED } 2}$ & 11 & 21 & 10 & 6 & 2 & 1 & 1 \\
\hline ISCED 3 & 5 & 8 & 0 & 11 & 3 & 3 & 3 \\
\hline
\end{tabular}

Textbooks from the post-war era did contain various types of other evolutionary diagrams but no phylogenetic trees. The most commonly used were Haeckel's trees of life implying the principle of scala naturae $(N=8)$, also five spindle diagrams and three chronograms were found, where two showed phylogeny partly as a linear change of one species to another (Jílek et al., 1982; Poupa \& Meisner, 1969). Only in one case, evolution was showed exclusively linear (evolution of hominids in Fleischmann et al., 1983).

A significant change in the amount and types of evolutionary diagrams between various editions of a single book was found only once. In textbooks for $9^{\text {th }}$ grade by SPN, the oldest edition contained a spindle diagram while the newest one was free of all searched visual elements (Pauk et al., 1972, 1980).

In the current textbooks, phylogenetic trees and other evolutionary diagrams (both further referred to as diagrams) were found in both ISCED 2 and 3 textbooks through their quality varied (see Fig. 5). Altogether, ten phylogenetic trees of various type were found. Though Haeckel's trees were not that common type of other evolutionary diagrams anymore, they still appeared in six cases. There were also eight spindle diagrams, but the most common were chronograms and other diagrams, which were commonly cladograms that did not conformed to the definition of phylogenetic tree used in this study. 


\subsection{Characteristics of diagrams}

In the post-war textbooks, $80 \%$ of all diagrams (both phylogenetic trees and other evolutionary diagrams) supported the idea of ladder thinking and showed unnecessary polytomies that were caused partly even by the shape of branches and unclear nodes due to avoiding clear $90^{\circ}$ angle design (Fig. 4).

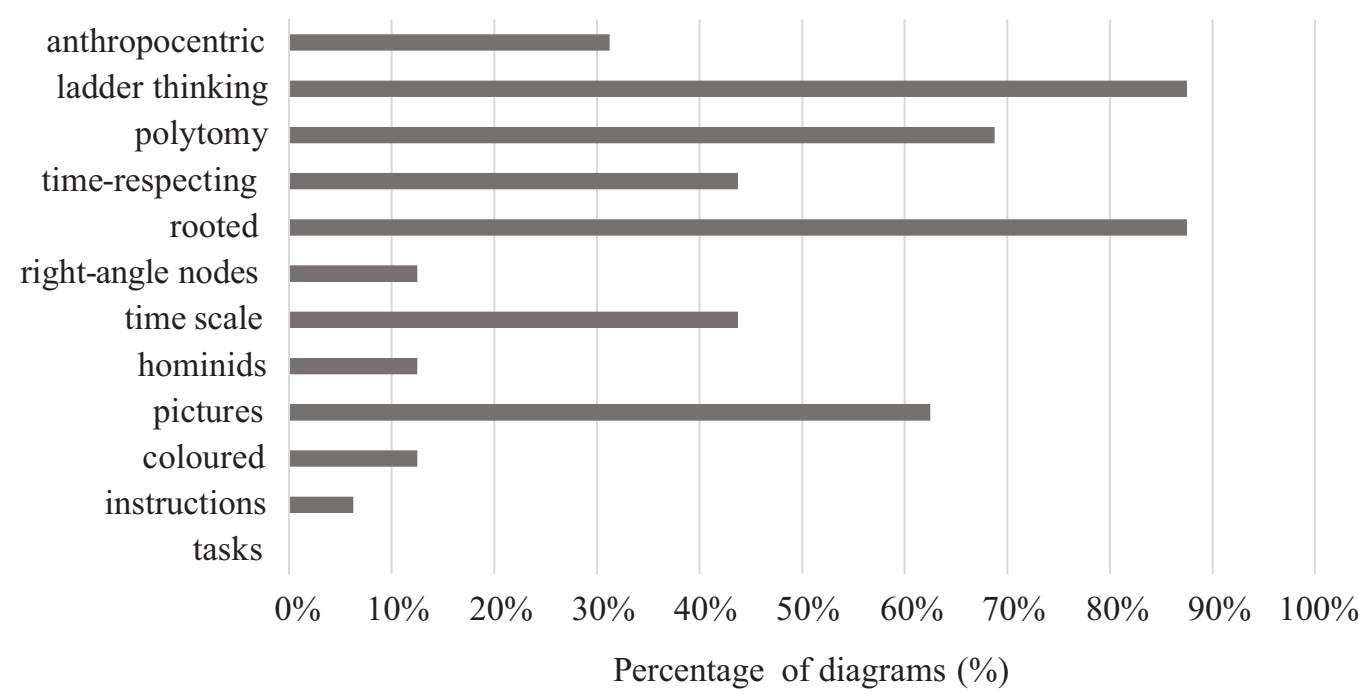

Fig. 4: Characteristics of all diagrams (both phylogenetic trees and other evolutionary diagrams, $N=18$ ) presented in post-war textbooks. As there were only two diagrams from two ISCED 2 textbooks, ISCED 2 and 3 textbooks are not divided

Diagrams presented in current textbooks often reinforced misconceptions (Fig. 5). $50 \%$ of ISCED 2 and $40 \%$ of ISCED 3 diagrams supported ladder thinking by aligning organisms at the branches' tips according to the complexity of their characteristics. Half of all diagrams also showed unnecessary polytomies.

More than $80 \%$ of diagrams in all current textbooks were rooted and more than $60 \%$ time-respecting (extant taxa equidistant from the root). No distinction between currently living (extant) and extinct taxa was more common in ISCED 3 textbooks. Only ten diagrams showed branches connected strictly at the $90^{\circ}$ angle, all were presented in ISCED 3 textbooks. In 10 out of all 14 ISCED 2 textbooks diagrams, branches were variously rounded at nodes, which made the precise points of the nodes less visible.

Any instructions on how to read the diagrams that would be placed right along the diagram itself were presented only in three ISCED 2 textbooks namely from Prodos and Fortuna (Dančák, 2015; Dančák \& Sedlářová, 2011; Kvasničková et al., 2018) and four ISCED 3 textbooks (Benešová et al., 2013; Flegr et al., 2017; Kvasničková, 2013; Šmarda, 2003). Still, these instructions were only very short and superficial. More than $90 \%$ of ISCED 3 textbooks lacked any tasks enabling active use of the diagrams during the lessons (Fig. 5).

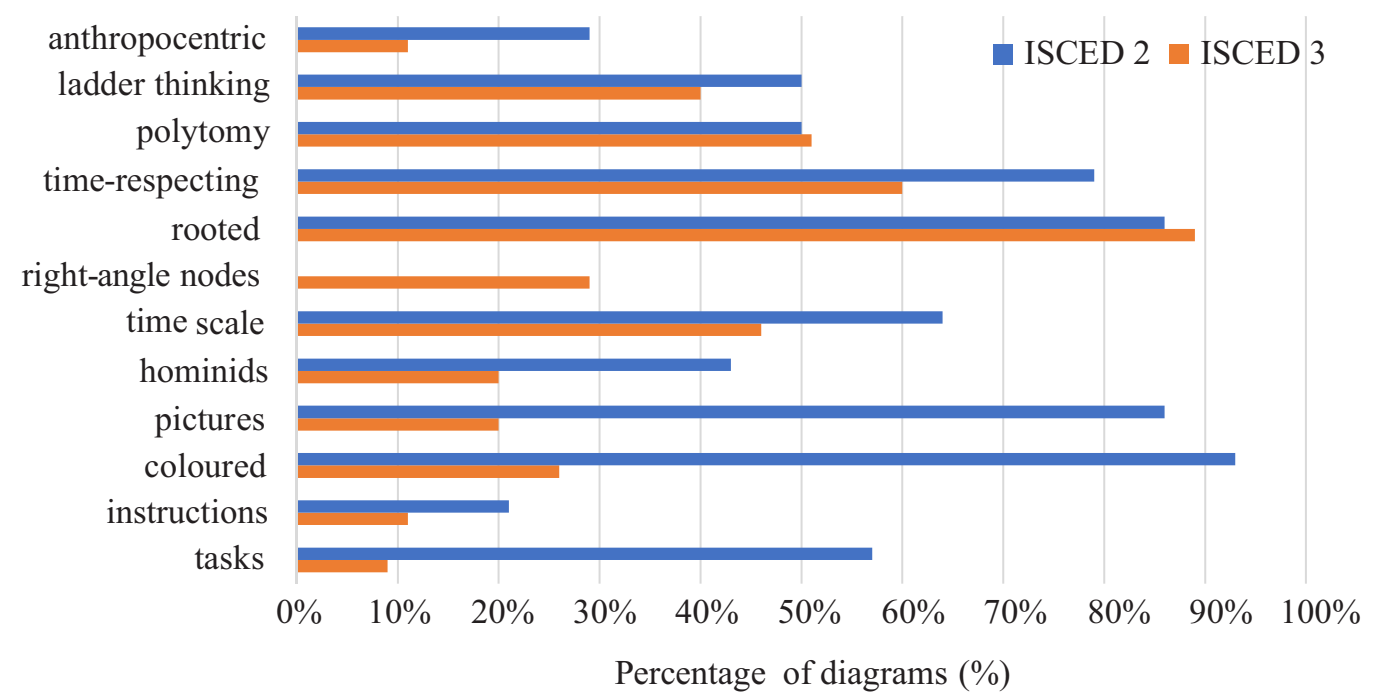

Fig. 5: Characteristics of all diagrams (phylogenetic trees and other evolutionary diagrams, $N=59$ ) found in the currently used textbooks (35 diagrams from ISCED 3 and 14 from ISCED 2 textbooks) 


\subsection{ISCED 2 textbooks' visual elements}

In ISCED 2 textbooks, phylogenetic trees and other evolutionary diagrams were overall less abundant, but in all cases either fully colourful or not entirely black and white (using colours combined with black and white silhouettes of species). Except for one diagram, they all contained pictures of introduced species.

Unfortunately, part of the diagrams contained very clear flaws. Diagrams of hominids evolution from three ISCED 2 textbooks partly showed evolution as a transformation of one species directly to the other one (Cílek et al., 2000; Drozdová et al., 2016; Pelikánová et al., 2016). Similarly, the textbook for $8^{\text {th }}$ grade by Prodos partly supported this idea (Navrátil, 2016), which was caused by the attempt to show both the species evolution as well as their expansion to the continents.

Diagrams of hominids evolution by Fraus and SPN textbooks for $8^{\text {th }}$ grade (Černík et al., 2015; Pelikánová et al., 2016) tended to be visibly anthropocentric (species sorting implies that the complexity grows from left to right). Though, the most visibly anthropocentric diagram was in the textbook for $9^{\text {th }}$ grade by Scientia, where humankind was placed in a very privileged position among other organisms and even distinguished by colour (Cílek et al., 2000).

This Haeckel-like tree diagram (Cílek et al., 2000) was also an example that evolutionary diagrams from ISCED 2 textbooks sometimes even lacked most information they could have shown (even relations among the taxa themselves). Similarly, as another tree diagram used in Prodos textbook for $6^{\text {th }}$ grade (Dančák \& Sedlářová, 2011), they gave only the information about the diversity of living organisms while also implying the scientifically wrong principle of scala naturae. Notably, the same types of diagrams were also included in the older textbooks edition by Prodos (Jurčák \& Froněk, 2004).

ISCED 2 textbooks often used the taxonomic overviews that served as a depiction of the diversity of organisms. Notably, textbooks for $6^{\text {th }}$ and $7^{\text {th }}$ grade by Taktik (Petrová et al., 2017; Žídková \& Knůrová, 2017) and Nová škola (Hedbávná et al., 2017) contained big overviews accompanied by colourful pictures that served as a good reminder of the organisms' diversity and the taxa that were introduced in the textbooks. Textbooks by Fraus for $7^{\text {th }}$ and $8^{\text {th }}$ grade (Pelikánová et al., 2015, 2016) used similar smaller overviews at the beginning of the new topics accompanied by silhouettes or photos of species. On the other hand, various textbooks (Dobroruka et al., 2010; Kvasničková et al., 2019, 2020; Maleninský et al., 2004) used big taxonomic overviews as supplementary material at the end of their textbooks in form of a plain list of taxa, not accompanied by any pictures.

There were various good examples of the use of evolutionary diagrams. Although there were certain violations of cladistics, diagrams of hominids evolution in the textbook for $8^{\text {th }}$ grade by Fraus (Pelikánová et al., 2016) were easy to read and helped to visualise the evolution. They contained pictures of both living and extinct species, showed additional information (timeline), and were even accompanied by simple tasks that enabled students to work with the diagrams (as "describe the evolution" and "name ancestors of humankind"). Looking at the older edition of the same book, it was visible that Fraus also updated and improved the diagram of hominids evolution (Vaněčková et al., 2006).

Another example was textbooks by Prodos that proved that even linear depictions of evolution implying the generally wrong ideas about the speciation process can be used in the right way. In the textbook for $8^{\text {th }}$ grade, a famous picture of an ape evolving in a linear row into the human was used but with the caption 'gradual straightening of the figure during the evolution of the hominids' (Navrátil, 2016). This caption completely changed the meaning of the picture, therefore, it was not even categorized as linear depiction. Still, this type of picture without caption or directly implying the linear evolution in its description was used in several other ISCED 2 textbooks (Matyášek, 2019; Matyášek \& Hrubý, 2019; Žídková \& Knůrová, 2018).

\subsection{ISCED 3 textbooks' visual elements}

Phylogenetic trees and other evolutionary diagrams were overall more abundant in textbooks aimed for ISCED 3 level. The mean for ISCED level 3 was 1.8 diagram per book, while for ISCED level 2 it was only 0.4 diagram per book. However, according to the principles of cladistics, the quality of diagrams in ISCED 3 textbooks varied even more.

ISCED 3 textbooks contained various spindle diagrams $(N=4)$, chronograms $(N=12)$, as well as uninformative Haeckel's trees of life $(N=4)$ implying the idea of ladder thinking. Mainly textbooks by Fortuna (Kincl et al., 2008; Smrž et al., 2004; Šmarda, 2003) and Olomouc (Jelínek \& Zicháček, 2007) introduced examples of phylogenetic trees resembling even the ones from professional biology journals (build clearly as tree or ladder cladograms with branches equidistant from the root).

Diagrams were proportionally less anthropocentric, though they still often supported ladder thinking as they tended to align organisms in left-right or top-down order from visually simpler to more complex (Smrž et al. 2004; Šmarda, 2003). The most unusual diagrams were introduced in 'Biologie v kostce' (Hančová \& Vlková, 2017) - though they were rooted, showing branching pattern, and claimed to be 
depictions of phylogeny, they violated several cladistics principles, contained unnecessary polytomies, and no pictures of species, which made them look more as confusing taxonomic overviews.

As ISCED 3 textbooks were often only black and white (or contains only coloured attachments with photographs), diagrams were less visually interesting and only one quarter of them contained any colours. Only fifth of them was accompanied by schematic pictures of species.

\section{Discussion and implications in practise}

The first phylogenetic tree was introduced already in 1859 in Darwin's 'Origin of species' (Darwin, 1859 , but it took a long time until evolutionary diagrams of any kind made their way into the Czech textbooks. With one exception of the evolutionary diagram (Bartušek, 1936), textbooks published before 1945 included only taxonomic overviews. During the post-war era, the abundance of evolutionary diagrams grew, but there were still no modern phylogenetic trees (cladograms or phylograms). Nevertheless, as modern phylogenetics is a young branch of biology sciences, it is no surprise that textbooks published before 1989 contained only a few evolutionary diagrams.

Although half of all currently used textbooks introduce bigger taxonomic overviews and all editions of ISCED 2 textbooks already introduce taxonomy and artificial taxa categorization, phylogenetics is in any form rather scarce to find. Biology education in the Czech Republic mostly uses the morphologicaltaxonomic approach while ordering topics in the school curriculum (Hlaváčová, 2017). The ability to assign organisms to their higher taxa is also demanded by the current national curriculum (NÚV, 2021). On the other hand, depictions of the relations among the taxa are not commonly used, mainly at ISCED level 2 . An older study showed that schemes represent on average only about $16 \%$ of all graphic elements in ISCED 2 biology textbooks (Hrabí, 2006). It reflects the low abundance of phylogenetic trees as threequarters of all ISCED 2 textbooks did not contain any diagram depicting evolution and relations among taxa.

If such diagrams were present in ISCED 2 and 3 textbooks, the majority of them did not conform to the modern cladistics or tended to variously support misconceptions about evolution and phylogenetics as a ladder or anthropocentric thinking. These problems were also recorded in textbooks used in USA (Catley \& Novick, 2008). In some cases, diagrams also implied the process of evolution partly as a linear change from one species to the other or explicit linear depictions of evolution were present. This was already found in a previous study on the humankind evolution in the Czech textbooks (Dvořáková \& Absolonová, 2017). Such graphic elements can negatively influence students' understanding of human evolution implying it as a gradual change from ape to human (Dvořáková \& Schierová, 2019).

Some diagrams even lacked most information about the taxa relations given by continuous use of Haeckel's trees of life (Cílek et al., 2000; Dančák \& Sedlářová, 2011; Jelínek \& Zicháček, 2007). Even though the captions of these diagrams pursued the intention to show mainly the diversity of living organisms, the same can be easily visualised in a big taxonomic overview accompanied by pictures of the introduced species. Similarly, spindle diagrams showed the abundance of taxa during the time but did not always clearly depicted their relations (Cílek et al., 2000; Smrž et al., 2004). Flaws in the diagrams' construction were sometimes even visibly caused by graphic designers trying to fit the picture on the page, as when the names of extant taxa were placed at the roots of branches and not at their tips (Kvasničková, 2018), or when the distinction of extinct and surviving taxa was unclear from the branches length though the extinct taxa were labelled with crosses (Jelínek \& Zicháček, 2007; Kočárek, 2010).

Similarly as in the USA textbooks (Catley \& Novick, 2008), phylogenetic trees and other evolutionary diagrams were mostly superficially described and lacking instructions on how to read and use them in lessons. Most of the diagrams in ISCED 3 textbooks contained only short captions describing them as the depictions of evolution or relations among showed taxa with no more information. Textbooks for both ISCED level 2 and 3 mostly did not explain how to read these diagrams or only simply described content of a diagram (as higher taxa names, time of their origin, the way lineages divided) though it was already proven that phylogenetic trees are not self-explanatory diagrams and without any guidance and instructions they are interpreted wrong by students (Novick et al., 2012).

Around $40 \%$ of ISCED 2 textbooks did not contain ideas for tasks enabling students to work with the presented diagrams actively in the lessons and most ISCED 3 textbooks did not introduce any such tasks. Notably, even textbooks for ISCED level 3 devoting whole chapters or longer parts of the text only to the cladistics principles and phylogenetics itself (Flegr et al., 2017; Kincl et al., 2008; Rosypal et al., 2003) showed only very few examples of cladograms on which students can apply their newly gained knowledge. Two ISCED 3 textbooks (Jelínek \& Zicháček, 2007; Smrž et al., 2004) also introduced the diagonal format of trees (ladder trees) that are not recommended to use as students find them much more difficult to understand than rectangular (tree) format (Novick et al., 2014). 
To conclude, the main problem of the evolutionary diagrams and particularly phylogenetic trees used in secondary textbooks is not just the reinforcement of misconceptions but also unfulfilled educational potential.

As many researchers showed, phylogenetics itself is hard for students to comprehend even at the university level (Dees et al., citemach13; Halverson et al., 2011; Kummer et al., 2016; Phillips et al., 2012). Therefore, ISCED 2 and 3 students cannot be expected to perform better. However, introducing outcomes of phylogenetics as a science at the secondary level should not be used to learn students how to construct the phylogenetic trees or understand detailed principles of molecular phylogenetic methods, but to comprehend the basic skills of reading such diagrams and acknowledging the message behind the very basic phylogenetic principles.

The aim of secondary science education is mainly to gain basic environmental and science literacy, therefore, phylogenetic trees should be used to facilitate students understanding of the evolution process and the position of humankind among other organisms (Sandvik, 2008). It had also been shown among university students that reading the trees is a much more comprehensible task than their construction (Halverson, 2011).

Phylogenetic trees are not just one of the main outcomes of modern science serving very valuable information, but they also facilitate active learning and help to battle both ladder thinking and misconception of linear evolution, which is still commonly used in illustrations in the popular culture and media as well as in many ISCED 2 textbooks as this study showed. Therefore, biology textbooks for higher grades of ISCED 2 and textbooks for all grades of ISCED 3 should introduce at least one phylogenetic tree as the most basic depictions of taxa relations rather than the explanation of uninformative and artificial Linnean categorization (as definitions of family, order, class etc.) (Sandvik, 2008).

On the other hand, phylogenetic trees used in the textbooks should respect students' cognitive development. As they mostly did not meet with phylogenetic trees before, they do not know how to read and deeply understand this specific type of diagram. This stresses the need to accompany all such diagrams with instructions on how to read them (Novick et al., 2012). Even very young kids (age 7-11) were able to understand phylogenetic trees much better given only short instructions (Ainsworth \& Saffer, 2013) and the same has been shown among university students (Phillips et al., 2012). As lectures strictly focused on phylogenetics are not obligatory at Czech faculties of education (as at the Charles University, the South Bohemian University, and the Masaryk University), these instructions will not serve just for students, but in many cases probably also for the teachers, which makes them even more important.

Authors of textbooks should always follow the basic cladistics principles during the construction of the used trees. At least some of these principles should be also described in the diagram's caption or the text, so students can navigate themselves how to read the presented tree correctly. This means statements like: all living organisms are at the tips of branches (in one line), branches can be turned at their nodes without changing the meaning (therefore, the species' order at the tips of the branches do not describe the species' complexity), lines and nodes of the branches do not represent extinct species but common ancestors, and so on.

As they tend to be very abstract, phylogenetic trees in the textbooks should be also more explicit than their counterparts in scientific journals and made easy to read using pictures of depicted species and preferably also clear timescale along with the right colour palette (for example to distinguish time periods or taxa). Rectangular trees should be also preferred over diagonal format (Novick et al., 2014). Although the branches connections do not have to be strictly at the right angle if it does not lead to the creation of artificial polytomies due to the poor visual differentiation of the nodes.

However, oversimplification of phylogenetic trees can result in nearly abstract pictures with no useful information (as Haeckel's trees of life). These can confuse the students and lead to the wrong understanding of taxa relations or origin (Sandvik, 2008), so they should not be used at all. In case the authors do not want to incorporate any phylogenetic trees, a much better option is to use a big taxonomic overview of taxa introduced in the book that will be accompanied by pictures of the most common or known species (see Fig. 6).

As supporting visualisations, phylogenetic trees can be great tools in hands of educators as a base for various problem tasks that enable active learning. For example, students can compare the morphology of related taxa to show examples of convergence and divergence during evolution, they can reconstruct the richness of human ancestors living at the same time on certain places on Earth, or reason which characteristics allows currently living taxa to survive. They can also answer some of the most popular biology questions like "Are we apes, or did we evolve from them?" or "Was it an egg or a hen that came first?" and many more. Such tasks can help students to deeper their understanding of many basic principles of science and should be more often embedded in science textbooks. There are already many other ideas for activities (Davenport et al., 2015; Gibson \& Cooper, 2017; McCullough et al., 2020) and whole educational models developed that can serve as an inspiration for teachers in practice both at 


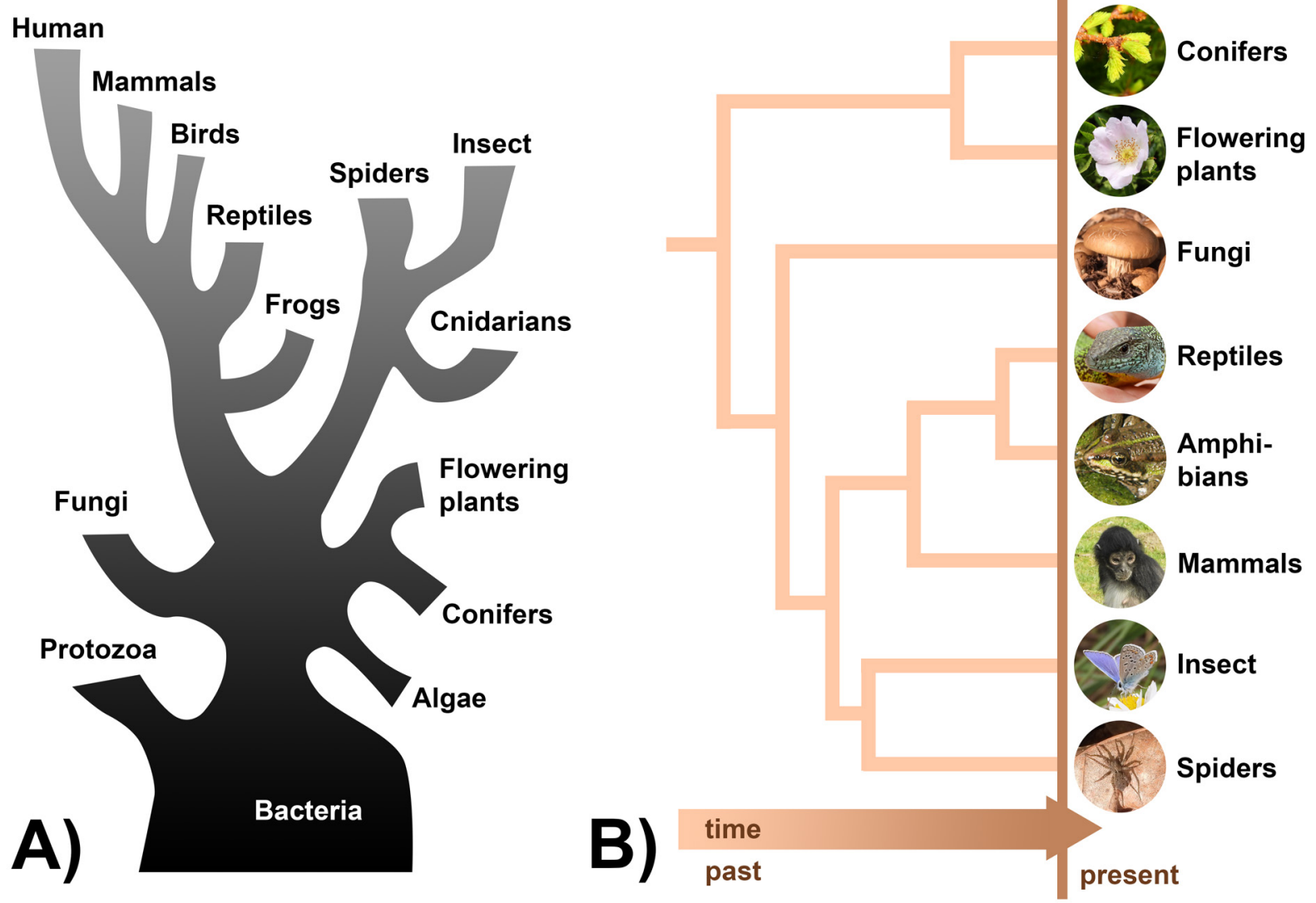

Fig. 6: Difference between evolutionary diagram promoting misconceptions and diagram made according to the basics of cladistics. On the left (A), there is a nearly abstract evolutionary diagram in a form of Haeckel's tree of life presenting some poly- or paraphyletic taxa. On the right (B), there is a modern colourful chronogram accompanied by pictures. In the left diagram (A), neither the thickness of branches nor their length has any meaning as well as their pattern. The diagram also implies ladder and anthropocentric thinking. In the diagram on the right (B), the branching pattern is clear, length of branches roughly represents time, and the diagram supports the tree thinking. (Used pictures made by the author.)

secondary and even at the university level (Eddy et al., 2013; Kong et al., 2017; Koupilová, 2020). Such activities can be also a very beneficial part of biology teachers' education. They can enable future teachers to gain a deeper understanding of the topic as well as adopt effective tools to help their own students in the future.

Many teachers complained to me that due to the recent growth of modern molecular methods phylogeny of organisms often changes, implying that textbooks will get outdated quickly after publishing. However, recent changes in the phylogeny of organisms did not affect most of those introduced in secondary textbooks neither their categorization, which is at the end only artificial (Sandvik, 2008). Also, outdated taxonomy seems to be a much bigger problem than phylogeny. Many textbooks used in this study still introduce such historical paraphyletic taxa as protozoans (Cerník et al., 2007; Musilová et al., 2018; Pelikánová et al., 2014; Vieweghová, 2019) and even the new editions of the same textbooks did not update this. Nevertheless, many various problems of outdated taxonomy and phylogeny in secondary textbooks are not the aim of this paper and will require a whole separate study itself.

As there are no exact records of all the Czech textbooks ever published and used in schools, this study does not have to include all of them. Therefore, the proportions of textbooks introducing phylogenetic trees and other evolutionary diagrams does not have to be definite but should represent at least the majority of textbooks, as various physical and digital archives were combined during the search.

\section{Conclusion}

Although the first diagram depicting relations between taxa was introduced in the Czech textbook in 1936, evolutionary diagrams became more abundant only later during the second half of the $20^{\text {th }}$ century and they were mostly supporting ladder thinking. 
While taxonomy and binomial nomenclature are common parts of the biology curriculum and current textbooks at both ISCED 2 and 3 educational levels, relations between presented taxa are still introduced scarcely in current secondary school textbooks.

Current textbooks for both ISCED level 2 and 3 still mostly present various evolutionary diagrams rather than modern phylogenetic trees and some of them do not even contain nearly any valuable information and many promote wrong understanding of principles of both evolution and phylogenetics.

On the other hand, correctly built phylogenetic trees can serve as a way how to effectively visualise organismal diversity and evolution and support general science literacy as well as students' active learning.

Therefore, ISCED 2 level textbooks should be accompanied with either big taxonomic overviews of the main taxa presented in the textbook or a simplified phylogenetic tree accompanied by guidance on how to read this type of diagram, problem tasks enabling its active use during the lessons, and preferably also pictures of species and timescale for better visualisation. The same goes for the ISCED 3 textbooks, where the use of various correctly build and described phylogenetic trees should be a standard.

The results of this study should not be understood the way that detailed cladistic principles and molecular phylogenetics have to be a part of secondary education, but the main outcomes of phylogenetics should be used to help students visualise and understand the basic biology concepts and natural processes as evolution that are part of the common science curriculum and also to prevent the rise of misconceptions about these concepts and processes.

\section{References}

Ainsworth, S., \& Saffer, J. (2013). Can children read evolutionary trees? Merrill-Palmer Quarterly, 59(2), 221. https://doi.org/10.13110/merrpalmquar1982.59.2.0221

Angielczyk, K. D. (2009). Dimetrodon is not a dinosaur: Using tree thinking to understand the ancient relatives of mammals and their evolution. Evolution: Education and Outreach, 2(2), 257-271. https://doi.org/10.1007/s12052-009-0117-4

Baum, D. (2008). Reading a phylogenetic tree: The meaning of monophyletic groups. Nature Education, 1(1), 190. https://www.nature.com/scitable/topicpage/reading-a-phylogenetic-tree-the-meaning-of-41956/

Byrne, J., Grace, M., \& Hanley, P. (2009). Children's anthropomorphic and anthropocentric ideas about micro-organisms. Journal of Biological Education, 44(1), 37-43. https://doi.org/10.1080/00219266.2009.9656190

Catley, K. M., \& Novick, L. R. (2008). Seeing the wood for the trees: An analysis of evolutionary diagrams in biology textbooks. BioScience, 58(10), 976-987. https://doi.org/10.1641/B581011

Cocks, S., \& Simpson, S. (2015). Anthropocentric and ecocentric: An application of environmental philosophy to outdoor recreation and environmental education. Journal of Experiential Education, 38(3), 216-227. https://doi.org/10.1177/1053825915571750

Coley, J. D., \& Tanner, K. D. (2012). Common origins of diverse misconceptions: cognitive principles and the development of biology thinking. CBE - Life Sciences Education, 11(3), 209-215. https://doi.org/10.1187/cbe.12-06-0074

Cornejová, I., Kasper, T., Kasperová, D., Kourová, P., Kratochvíl, P., Lenderová, M., Novotný, M., Pokorný, J., Svatoš, M., Svobodný, P., Šimek, J., \& Váňová, R. (2020). Velké dějiny zemí Koruny české: školství a vzdělanost (M. Novotný (ed.)). [Great history of the Lands of the Bohemian Crown: Education.] Paseka.

Darwin, C. (1859). On the origin of species by means of natural selection, or, the preservation of favoured races in the struggle for life. John Murray.

Davenport, K., Milks, K. J., \& Tassell, R. Van. (2015). Investigating tree thinking \& ancestry with cladograms. The American Biology Teacher, 7r(3), 198-204. https://doi.org/10.1525/abt.2015.77.3.8

Dayrat, B. (2003). The roots of phylogeny: How did Haeckel build his trees? Systematic Biology, 52(4), 515-527. https://doi.org/10.1080/10635150390218277

Dees, J., Bussard, C., \& Momsen, J. L. (2018). Further effects of phylogenetic tree style on student comprehension in an introductory biology course. CBE - Life Sciences Education, 17(2), ar17. https://doi.org/10.1187/cbe.17-03-0058

Dees, J., Momsen, J. L., Niemi, J., \& Montplaisir, L. (2014). Student interpretations of phylogenetic trees in an introductory biology course. CBE - Life Sciences Education, 13(4), 666-676.

https://doi.org/10.1187/cbe.14-01-0003

Diogo, R., Ziermann, J. M., \& Linde-Medina, M. (2015). Is evolutionary biology becoming too politically correct? A reflection on the scala naturae, phylogenetically basal clades, anatomically plesiomorphic taxa, and 'lower' animals. Biological Reviews, 90(2), 502-521. https://doi.org/10.1111/brv.12121 
Dvořáková, R. M., \& Absolonová, K. (2017). Obsahová analýza tématu evoluce člověka v českých učebnicích př́rodopisu a biologie [Content analysis of Czech school biology textbook with regard to human evolution topics]. Scientia in Educatione, 8(2), 2-20. https://doi.org/10.14712/18047106.765

Dvořáková, R., \& Schierová, Z. (2019). Co už o vzniku a vývoji člověka raději neučit [What better not to teach about the origin and development of humankind?]. Arnica, 9(2), 59-65.

https://www.arnica.zcu.cz/images/casopis/2019/Arnika_2019_2-2-Dvorakova-Schierova-web.pdf

Eddy, S. L., Crowe, A. J., Wenderoth, M. P., \& Freeman, S. (2013). How should we teach tree-thinking? An experimental test of two hypotheses. Evolution: Education and Outreach, 6(1), 13.

https://doi.org/10.1186/1936-6434-6-13

Felsenstein, J. (1985). Phylogenies and the comparative method. The American Naturalist, 125(1), 1-15. https://courses.helsinki.fi/sites/default/files/course-material/4523940/Felsenstein85.pdf

Gibson, J. P., \& Cooper, J. T. (2017). Botanical phylo-cards: A tree-thinking game to teach plant evolution. The American Biology Teacher, 79(3), 241-244. https://doi.org/10.1525/abt.2017.79.3.241

Gregory, T. R. (2008). Understanding evolutionary trees. Evolution: Education and Outreach, 1(2), $121-137$. https://doi.org/10.1007/s12052-008-0035-x

Halverson, Kristy L., Pires, C. J., \& Abell, S. K. (2011). Exploring the complexity of tree thinking expertise in an undergraduate systematics course. Science Education, 95(5), 794-823. https://doi.org/10.1002/sce.20436

Halverson, K. L. (2011). Improving tree-thinking one learnable skill at a time. Evolution: Education and Outreach, 4(1), 95-106. https://doi.org/10.1007/s12052-010-0307-0

Hlaváčová, L. (2017). Systematický přístup prezentace učiva přírodopisu/biologie [Taxonomically conceived curriculum of natural science/biology]. Biologie. Chemie. Zeměpis, 26(3), 40-44.

https://doi.org/10.14712/25337556.2017.3.6

Hoßfeld, U., Watts, E., \& Levit, G. S. (2017). The first Darwinian phylogenetic tree of plants. Trends in Plant Science, 22(2), 99-102. https://doi.org/10.1016/j.tplants.2016.12.002

Hrabí, L. (2006). An evaluation of graphical information presented in biology textbooks. E-Pedagogium, 6(1), 26-32. https://e-pedagogium.upol.cz/artkey/epd-200601-0002_hodnoceni-graficke-informace-ucebnic-prirodopisu.php

Kong, Y., Thawani, A., Anderson, T., \& Pelaez, N. (2017). A model of the use of evolutionary trees (MUET) to inform K-14 biology education. The American Biology Teacher, 79(2), 81-90.

https://doi.org/10.1525/abt.2017.79.2.81

Kopnina, H. (2014). Revisiting education for sustainable development (ESD): Examining anthropocentric bias through the transition of environmental education to ESD. Sustainable Development, 22(2), 73-83. https://doi.org/10.1002/sd.529

Koupilová, K. (2020). Orientační běh napříč skupinami organismů - výukový blok o sestavování a čtení evolučních stromů [Navigating among animals and plants - educational activities on construction and reading of evolutionary trees]. Biologie. Chemie. Zeměpis, 29(1), 1-1. https://doi.org/10.14712/25337556.2020.1.2

Kummer, T. A., Whipple, C. J., \& Jensen, J. L. (2016). Prevalence and persistence of misconceptions in tree thinking. Journal of Microbiology \& Biology Education, 17(3), 389-398. https://doi.org/10.1128/jmbe.v17i3.1156

McCullough, E. L., Verdeflor, L., Weinsztok, A., Wiles, J. R., \& Dorus, S. (2020). Exploratory activities for understanding evolutionary relationships depicted by phylogenetic trees: United but diverse. The American Biology Teacher, 82(5), 333-337. https://doi.org/10.1525/abt.2020.82.5.333

McLennan, D. A. (2010). How to read a phylogenetic tree. Evolution: Education and Outreach, 3(4), 506-519. https://doi.org/10.1007/s12052-010-0273-6

Meisel, R. P. (2010). Teaching tree-thinking to undergraduate biology students. Evolution: Education and Outreach, 3(4), 621-628. https://doi.org/10.1007/s12052-010-0254-9

Mivart, S. G. (1865). Contributions towards a more complete knowledge of the axial skeleton in the primates. Proceedings of the Zoological Society of London, 33(1), 545-592.

https://doi.org/10.1111/j.1469-7998.1865.tb02387.x

Morrison, D. A. (1996). Phylogenetic tree-building. International Journal for Parasitology, 26(6), 589-617. https://doi.org/10.1016/0020-7519(96)00044-6

Novick, L. R., \& Catley, K. M. (2016). Fostering 21st-century evolutionary reasoning: Teaching tree thinking to introductory biology students. CBE - Life Sciences Education, 15(4), 1-12.

https://doi.org/10.1187/cbe.15-06-0127

Novick, L. R., Schreiber, E. G., \& Catley, K. M. (2014). Deconstructing evolution education: The relationship between micro- and macroevolution. Journal of Research in Science Teaching, 51(6), 759-788.

https://doi.org/10.1002/tea.21161 
Novick, L. R., Stull, A. T., \& Catley, K. M. (2012). Reading phylogenetic trees: The effects of tree orientation and text processing on comprehension. BioScience, —it 62(8), 757-764. https://doi.org/10.1525/bio.2012.62.8.8

NÚV. (2021). Rámcový vzdělávací program pro základní vzdělávání [Framework education programme for elementary education]. MŠMT. http://www.nuv.cz/file/4983/

Omland, K.E., Cook, L. G., \& Crisp, M. D. (2008). Tree thinking for all biology: The problem with reading phylogenies as ladders of progress. BioEssays, 30(9), 854-867. https://doi.org/10.1002/bies.20794

Phillips, B. C., Novick, L. R., Catley, K. M., \& Funk, D. J. (2012). Teaching tree thinking to college students: It's not as easy as you think. Evolution: Education and Outreach, 5(4), 595-602.

https://doi.org/10.1007/s12052-012-0455-5

Podani, J. (2019). The coral of life. Evolutionary Biology, 46(2), 123-144.

https://doi.org/10.1007/s11692-019-09474-w

Reddy, B. P. N. (2011). Basics for the construction of phylogenetic trees. WebmedCentral BIOLOGY, 2(12). https://doi.org/10.9754/journal.wmc.2011.002563

Sa'adah, S., Hidayat, T., \& Sudargo, F. (2017). Undergraduate students' initial ability in understanding phylogenetic tree. Journal of Physics: Conference Series, 824, 012040.

https://doi.org/10.1088/1742-6596/824/1/012040

Sandvik, H. (2008). Tree thinking cannot taken for granted: challenges for teaching phylogenetics. Theory in Biosciences, 127(1), 45-51. https://doi.org/10.1007/s12064-008-0022-3

Schneider, B., Strait, M., Muller, L., Elfenbein, S., Shaer, O., \& Shen, C. (2012). Phylo-Genie: Engaging students in collaborative "tree-thinking" through tabletop techniques. Proceedings of the 2012 ACM Annual Conference on Human Factors in Computing Systems - CHI '12, 3071-3080. https://doi.org/10.1145/2207676.2208720

Schramm, T., Schachtschneider, Y., \& Schmiemann, P. (2019). Understanding the tree of life: an overview of tree-reading skill frameworks. Evolution: Education and Outreach, 12(11), 1-13. https://doi.org/10.1186/s12052-019-0104-3

Scott, A. D., \& Baum, D. A. (2016). Phylogenetic tree. In Encyclopedia of Evolutionary Biology (pp. 270-276). Academic Press. https://doi.org/10.1016/B978-0-12-800049-6.00203-1

Wiens, J. J. (2004). The role of morphological data in phylogeny reconstruction. Systematic Biology, 53(4), 653-661. https://doi.org/10.1080/10635150490472959

Yang, Z., \& Rannala, B. (2012). Molecular phylogenetics: principles and practice. Nature Reviews Genetics, 13(5), 303-314. https://doi.org/10.1038/nrg3186

Ypma, R. J.F., van Ballegooijen, W. M., \& Wallinga, J. (2013). Relating phylogenetic trees to transmission trees of infectious disease outbreaks. Genetics, 195(3), 1055-1062. https://doi.org/10.1534/genetics.113.154856

Zachos, F. E. (2016). Tree thinking and species delimitation: Guidelines for taxonomy and phylogenetic terminology. Mammalian Biology, 81(2), 185-188. https://doi.org/10.1016/j.mambio.2015.10.002

Zrzavý, J., Storch, D., \& Mihulka, S. (2004). Jak se dělá evoluce: od sobeckého genu k rozmanitosti života [How evolution is done: From the selfish gene to the diversity of life]. Paseka.

\section{Appendix}

\section{Appendix 1: List of analysed textbooks}

Textbooks published before 1990 are sorted according to the year of publishing, current textbooks are in alphabetical order.

\section{Part A) Archaic (1859-1917)}

Procházka, J. (1862). V̌̌eobecný nerostopis pro gymnasia i reálky. 2. vydání. Jindřichův Hradec: A. J. Landfrass a syn.

Jehlička, P. (1865). Krátký př́rodopis rostlin: Pro nižši oddělení středních škol. Praha: B. Stýbl.

Jehlička, P. (1866). Stručný př́rodopis všech tř́ ř́iš́: pro mládež vưbec a pro čtvrté tř́dy hlavních škol zvlášt. Praha: B. Stýbl.

Švácha, F. (1876). Př́rodopis živočišstva. I. L. Kober.

Frič, A. (1875). Př́rodopis živočišstva pro vyšši gymnasialní a realni školy. Praha: B. Tempský. 
Pokorný, A., \& Bořický, E. (1875). Dra A. Pokorného názorný nerostopis: pro nižši oddělení středních škol českoslovanských. Praha: B. Tempský.

Ždímal, B. (1876). Učebná kniha přírodopisu, tělo- a zdravovědy pro třetí tř́du škol měštanských. Praha: I. L. Kober.

Bořický, E. (1876). Nerostopis pro vyšši gymnasiálni a realni školy. Praha: B. Tempský.

Pokorný, A., \& Celakovský, L. J. (1893). Názorný př́rodopis rostlinstva: pro nižší oddělení středních škol československých. 6. přepracované vydání. Praha: F. Tempský.

Pokorný, A., \& Rosický, F. V. (1894). Názorný př́rodopis živočišstva: pro nižší oddělení středních škol českoslovanských. 8. vydání. Praha: F. Tempský.

Pokorný, A., \& Rosický, J. (1898). Přírodopis pro školy měštanské. 11. vydání. Praha: F. Tempský.

Nosek, A. (1906). Zoologie pro vyšši třídy středních škol. Praha: Česká grafická unie.

Rosický, F. V., \& Rosický, J. (1909). Rostlinopis pro ústavy ku vzdělání učitelů a učitelek. Česká grafická unie v Praze.

\section{Part B) Historical (1918-1948)}

Rosický, J. (1920). Přírodopis pro školy měštanské: na základě biologickém. Praha: Ceská grafická unie, a.s.

Nosek, A. (1921). Př́rodopis živočišstva pro nižši tř́dy středních škol: podle pozorování života v přírodě. 2. vydání. Praha: I. L. Kober.

Kolisko, H. T. (1925). Malý přírodopis: část I. - savci a ptáci. 17. vydání. Praha: Grafické závody Neuber, Pour a spol.

Urban, J. V., \& Hanuš, J. (1925). Přírodopis pro měštanské školy: Díl II. 5. opravené vydání. Praha: Ignác Leopold Kober.

Vlach, V., \& Krejčík, J. (1931). Př́rodopis pro jednoročni učebné kursy (IV. třídy) při měštanských školách. Praha: Ceská grafická unie, a.s.

Daněk, G. (1933). Zoologie a somatologie pro učitelské ústavy. Praha: Československá grafická unie.

Polívka, F. (1933). Živočichopis pro I. a II. třídu středních škol. 13. nezměněné vydání. Olomouc: R. Promberger.

Krejčík, J. (1934). Př́rodověda pro druhou tř́du měštanských škol: normálních i pokusných. Praha: Československá grafická unie, a.s.

Groulík, J., Úlehla, J., Hampl, R., Broul, F., \& Herodes, K. (1934). Př́rodověda pro I. tř́du měštanských škol. 15. přepracované vydání. Olomouc: R. Promberger.

Polívka, F., \& Daněk, G. (1935). Rostlinopis a nauka o zemi pro I. a II. tř́du středních škol. Olomouc: R. Promberger.

Filip, D., \& Šmika, R. (1935). Rok v př́rodě: úvod do přirodních věd pro druhou tř́du středních škol. Praha: Ceskoslovenská grafická unie.

Bartušek, V. (1936). Rostlinopis se všeobecným závěrem botaniky: pro vy̌š̌i tř́dy středních škol a učitelské ústavy. Praha: Československá grafická unie, a.s.

Groulík, J., Úlehla, J., Hampl, R., Broul, F., \& Úlehla, V. (1936). Př́rodopis pro II. třídu měštanských škol. 12. přepracované vydání. Olomouc: R. Promberger.

Pastejř́ík, J. (1936). Př́rodopis (užitá biologie) pro jednoroční učebné kursy (IV. tř́dy) př́i měštanských školách. 2. nezměněné vydání. Praha: Komenium.

Fendrych, M. (1939). Přehled př́rodovědy pro školy 2. stupně (měštanské a nižší střední) a soukromé studium: svazek I. - Př́rodověda obecná. Praha: Ceská grafická unie.

Fendrych, M. (1939). Přehled př́rodovědy pro školy 2. stupně (měštanské a nižší střední) a soukromé studium: svazek VII. - Biologie. Praha: Ceská grafická unie.

Fendrych, M. (1939). Přehled př́rodovědy pro školy 2. stupně (měštanské a nižší střední) a soukromé studium: svazek VIII. - Botanika. Praha: Čská grafická unie.

Fendrych, M. (1939). Přehled př́rodovědy pro školy 2. stupně (měštanské a nižši střední) a soukromé studium: svazek IX. - Zoologie. Praha: Česká grafická unie.

Řehák, B. (1945). Botanika pro vyšši třídy středních škol a učitelské ústavy. Praha: Ceská grafická unie.

Fendrych, M. (1947). Biologie pro nejvyšši tř́du středních škol. Praha: Česká grafická unie. 


\section{Part C) C. I: Post-war (1949-1989)}

Vodička, A., Meisner, J., Vršanský, V., \& Fügnerová, M. K. (1950). Nauka o člověku: učební text pro třetí tř́du střednich škol. Praha: SPN.

Bartoš, E., Kramář, J., Novák, V. \& Pelíšek, R. (1953). Zoologie: Učební text pro druhou třídu středních škol. 4. vydání. Praha: SPN.

Roubal, J., \& Zima, K. (1963). Zoologie pro 6. ročník základních devítiletých škol. Edice Učebnice pro základní devítileté školy. 1. vydání. Praha: SPN.

Trávníček, T., \& Janda, F. (1965). Biologie člověka pro III. ročník středních všeobecně vzdělávacích škol, př́rodovědná větev. Praha: SPN.

Jeník, J., Pazourek, J., Roubal, J., Střihavková, H., \& Šmídová, M. (1967). Botanika pro I. ročník středních všeobecně vzdělávacích škol. Praha: SPN.

Daněk, G. (1967). Zoologie pro 1. a 2. ročník středních všeobecně vzdělávacích škol. 2. vydání. Praha: SPN.

Poupa, O., \& Meisner, J. (1969). Biologie člověka pro II. ročník všeobecně vzdělávacích škol. 3. vydání. Praha: SPN.

Hainer, V., Hnízdo, A., Ličková, M., \& Trávníček, T. (1972). Př́rodopis pro 8. ročník základních devítiletých škol (Biologie člověka). Praha: SPN.

Pauk, F., Augusta, J., Dvořák, J., Smolíková, L., \& Vodička, A. (1972). Přírodopis 9: Mineralogie, geologie, vývoj života. 8. vydání. Praha: SPN.

Pauk, F., Kühn, P., Sluštík, S., Kočárek, E., \& Kletečka, J. (1976). Mineralogie, petrografie a geologie pro 1. ročník gymnázií. Praha: SPN.

Boháč, I., Kvasničková, D., Nečas, O., \& Šmarda, J. (1976). Obecná biologie: pro IV. ročník gymnázií. SPN.

Jeník, J., Pazourek, J., Roubal, J., Střihavková, H., \& Šmídová, M. (1977). Botanika pro II. ročník gymnázií. 5. vydání. Edice Učebnice pro střední všeobecně vzdělávací školy. Praha: SPN.

Šula, J. (1978). Botanika pro 6. ročník základních devítiletých škol. Edice Učebnice pro základní devítileté školy. 10. nezměněné vydání. Praha: SPN.

Daněk, G. (1978). Zoologie pro III. ročník gymnázií. Edice: Učebnice pro střední školy. 5. vydání. Praha: SPN.

Pauk, F., Augusta, J., Dvořák, J., Smolíková, L., \& Vodička, A. (1980). Př́rodopis 9: Mineralogie, geologie, vývoj života. 16. vydání. Praha: SPN.

Vilček, F., Lišková, E., Altmann, A., \& Korábová, A. (1981). Př́rodopis 6: pro 6. ročník základní školy. Praha: SPN.

Júlek, L., Trávníčková, E., Fišer, J., \& Suchý, J. (1982). Biologie člověka: pro IV. ročník gymnázii. 6 . nezměněné vydání. Praha: SPN.

Hoja, Š. (1982). Biologie: učebnice pro střední zdravotnické školy. 2. vydání. Praha: Avicenum.

Fleischmann, J., Linc, R., Dostál, P., \& Rošická, L. (1983). Přírodopis 7: pro \%. ročník základní školy. 2. vydání. Praha: SPN.

Lenochová, M., Nečas, O., Dvořák, F., Vilček, F., \& Boháč, I. (1984). Biologie pro I. ročník gymnázia. Bratislava: SPN.

Bašovská, M., Halásová, R., Nečas, O., Pastýrik, L., Trojanová, M., Šmarda, J., Boháč, I., \& Stoklasa, J. (1985). Biologie pro II. ročník gymnázií. Praha: SPN.

\section{II: Other editions compared}

(different editions of the same textbook that were compared and their content on the researched topics was the same)

Hainer, V., Hnízdo, A., Ličková, M., \& Trávníček, T. (1970). Přírodopis pro 8. ročník základních devítiletých škol (Biologie člověka). Praha: SPN.

Pauk, F., Augusta, J., Dvořák, J., Smolíková, L., \& Vodička, A. (1979). Přírodopis 9: Mineralogie, geologie, vývoj života. Praha: SPN.

Boháč, I., Kvasničková, D., Nečas, O., \& Šmarda, J. (1981). Obecná biologie: pro IV. ročník gymnázií. Praha: SPN.

Fleischmann, J., Linc, R., Dostál, P., \& Rošická, L. (1985). Př́rodopis 7: pro \%. ročník základní školy. 2. vydání. Praha: SPN. 


\section{Part D) Currently used (published after 1990)}

\section{I: ISCED 2 - newest editions}

Břicháčková, E., \& Francová, M. (2019). Př́rodopis 8: Savci a člověk. Edice Čtení s porozuměním. Brno: Nová škola - DUHA.

Cílek, V., Matějka, D., Mikuláš, R., \& Ziegler, V. (2000). Př́rodopis IV pro 9. ročník základni školy. 1. vydání. Praha: Scientia.

Černík, M., Hamerská, M., Martinec, Z., \& Vaněk, J. (2016). Př́rodopis 7: zoologie a botanika pro základní školy. 2. vydání. Praha: SPN.

Cerník, V., Hamerská, M., Martinec, Z., \& Vaněk, J. (2007). Př́rodopis 6 pro základní školu: zoologie a botanika. Praha: SPN.

Černík, V., Martinec, Z., \& Vodová, V. (2015). Přírodopis 8 pro základni školy: biologie člověka. 2. vydání. Praha: SPN.

Černík, V., Martinec, Z., Vítek, J., \& Vodová, V. (2016). Př́rodopis 9 pro základni školu: geologie a ekologie. Praha: SPN.

Dančák, M. (2015). Přírodopis 6: Rostliny. Olomouc: Prodos. ISBN 978-80-7230-294-9.

Dančák, M., \& Sedlářová, M. (2011). Př́rodopis 6: vývoj života na Zemi - obecná biologie - biologie hub. Olomouc: Prodos.

Dobroruka, L. J., Gutzerová, N., Havel, L., Chocholoušková, Z., \& Kučera, T. C. (2003). Př́rodopis II pro 7. ročník základni školy. 2. vydání. Praha: Scientia.

Dobroruka, L. J., Cílek, V., Hasch, F., \& Storchová, Z. (1999). Př́rodopis I pro 6. ročník základní školy. 2. vydání. Praha: Scientia.

Dobroruka, L. J., Vacková, B., Králová, R., \& Bartoš, P. (2010). Přírodopis III pro 8. ročník základni školy. 3. vydání. Praha: Scientia.

Drozdová, E., Klinkovská, L., \& Lízal, P. (2016). Př́rodopis 8: Biologie člověka. Brno: Nová škola, s. r. o.

Faměra, M., Dančák, M., \& Kuras, T. (2017). Přírodopis 9: Geologie - Ekologie. Olomouc: Prodos.

Hedbávná, H., et al. (2017). Př́rodopis 2. díl: Botanika. 3. aktualizované vydání. Brno: Nová škola, s. r. o.

Kočárek, P., Mikulenková, H., \& Ševčík, D. (2016). Př́rodopis 7: Živočichové. Olomouc: Prodos.

Kvasničková, D., Faierajzlová, V., Froněk, J., \& Pecina, P. (2016). Ekologický př́rodopis pro 8. ročník základní školy. 3. upravené vydání. Praha: Fortuna.

Kvasničková, D. J., Jeník, J., Pecina, P., Froněk, \& Cais, J. (2016). Ekologický př́rodopis pro \%. ročník základní školy - 2. část. 4. upravené vydání. Praha: Fortuna.

Kvasničková, D., Jeník, J., Pecina, P., Froněk, J., \& Cais, J. (2020). Ekologický přírodopis pro 6. ročník základní školy. 4. upravené vydání. Praha: Fortuna.

Kvasničková, D., Jeník, J., Pecina, P., Froněk, J., \& Cais, J. (2019). Ekologický přírodopis pro 7. ročník základní školy - 1. část. 5. upravené vydání. Praha: Fortuna.

Kvasničková, D., Jeník, J., Tonika, J., \& Froněk, J. (2018). Ekologický přírodopis pro 9. ročník základni školy. 3. upravené vydání. Praha: Fortuna.

Maleninský, M., \& Vacková, B. (2005). Př́rodopis pro 8. ročník - Člověk: učebnice pro základní školy a nižší stupeñ víceletých gymnázii. Edice Natura. Praha: Nakladatelství České geografické společnosti.

Maleninský, M., Novák, J., Švecová, M., \& Toběrná, V. (2006). Přírodopis pro \%. ročník zoologie 2, botanika 2: učebnice pro základní školy a nižší stupeň víceletých gymnázií. Edice Natura. Praha: Nakladatelství Ceské geografické společnosti.

Maleninský, M., Smrž, J., \& Škoda, B. (2004). Přírodopis pro 6. ročník - Botanika 1, Zoologie 1: učebnice pro základni školy a nižši stupeň víceletých gymnázií. Edice Natura. Praha: Nakladatelství České geografické společnosti.

Matyášek, J. (2019). Přírodopis 9: Geologie a ekologie. Edice Čtení s porozuměním. Brno: Nová škola - DUHA.

Matyášek, J., \& Hrubý, Z. (2019). Př́rodopis 9: Geologie a ekologie. 5. aktualizované vydání. Brno: Nová škola, s.r.o.

Musilová, E., Koněpotský, A., \& Vlk, R. (2018). Př́rodopis 1. díl: Úvod do učiva přírodopisu. 4. aktualizované vydání. Brno: Nová škola, s. r. o. 
Navrátil, M. (2016). Přírodopis 8: Člověk. Olomouc: Prodos.

Pelikánová, I., Cabradová, V., Hasch, F., \& Sejpka, J. (2014). Přírodopis 6: učebnice základní školy a víceletá gymnázia - nová generace. Plzeň: Fraus.

Pelikánová, I., Cabradová, V., Hasch, F., \& Sejpka, J. (2015). Přírodopis 7: učebnice základní školy a víceletá gymnázia - nová generace. Plzeň: Fraus.

Pelikánová, I., Skýbová, J., Markvartová, D., Hejda, T., Vančata, V., \& Hájek, M. (2016). Př́rodopis 8: učebnice pro základní školy a víceletá gymnázia - nová generace. Plzeň: Fraus.

Petrová, D., Žídková, H., \& Knůrová, K. (2017). Hravý př́rodopis 7: učebnice pro \%. ročník ZS̆ a víceletá gymnázia. Praha: Taktik International.

Rychnovský, B., Odstrčil, M., Popelková, P., \& Kubešová, S. (2017). Př́rodopis 1. díl: Strunatci.

3. aktualizované vydání. Brno: Nová škola, s.r. o.

Švecová, M., \& Matějka, D. (2017). Př́rodopis 9: učebnice pro základní školy a víceletá gymnázia - nová generace. Plzeň: Fraus.

Vieweghová, T. (2019). Přírodopis 6: Úvod do přírodopisu. Edice Čtení s porozuměním. Brno: Nová škola DUHA.

Vieweghová, T., et al. (2019). Př́rodopis 7: Zoologie a botanika. Edice Čtení s porozuměním. Brno: Nová škola - DUHA.

Vlk, R., \& Kubešová, S. (2018). Přírodopis 2. díl: Bezobratlí živočichové. 4. aktualizované vydání. Brno: Nová škola, s.r.o.

Žídková, H., \& Knůrová, K. (2017). Hravý př́rodopis 6: učebnice pro 6. ročník ZS̆ a víceletá gymnázia. Praha: Taktik International.

Žídková, H., \& Knůrová, K. (2018). Hravý př́rodopis 8: učebnice pro 8. ročník ZS̆ a víceletá gymnázia. Praha: Taktik International.

Žídková, H., \& Knůrová, K. (2019). Hravý př́rodopis 9: učebnice pro 9. ročník ZŚ a víceletá gymnázia. Praha: Taktik International.

\section{II: ISCED 2 - older editions (only discussed)}

Vaněčková, I., Skýbová, J., Markvartová, D., \& Hejda, T. (2006). Př́rodopis 8: učebnice pro základni školy a víceletá gymnázia. 1. vydání. Plzeň: Fraus.

Jurčák, J., \& Froněk, J. (2004). Přírodopis 6. 2. aktualizované vydání. Olomouc: Prodos.

\section{III: ISCED 3}

Benešová, M., Hamplová, H., Knotová, K., Lefnerová, P., Pfeiferová, E., Sáčková, I., \& Satrapová, H. (2013). Odmaturuj! z biologie. Edice Odmaturuj. 2. vydání. Brno: Didaktis.

Flegr, J., Kaňková, Š., Lindová, J., \& Synek, P. (2017). Základy evoluční biologie. Edice Biologie pro gymnázia. Praha: Scientia.

Hančová, H., \& Vlková, M. (2017). Biologie v kostce pro SS̆. Dotisk 1. vydání. Praha: Fragment.

Jelínek, J., \& Zicháček, V. (2007). Biologie pro gymnázia (teoretická a praktická část). 9. vydání. Olomouc: Olomouc.

Kincl, L., Kincl, M., \& Jarklová, J. (2008). Biologie rostlin pro 1. ročník gymnázií. 4. přepracované vydání. Praha: Fortuna.

Kočárek, E. (2004). Genetika: obecná genetika a cytogenetika, molekulární biologie, biotechnologie, genomika. Edice Biologie pro gymnázia. Praha: Scientia.

Kočárek, E. (2010). Biologie člověka 1. Edice Biologie pro gymnázia. Praha: Scientia.

Kočárek, E. (2012). Biologie člověka 2. Edice Biologie pro gymnázia. Praha: Scientia.

Kubát, K., Kalina, T., Kováč, J., Kubátová, D., Prach, K., \& Urban, Z. (2003). Botanika. 2. vydání. Praha: Scientia.

Kubišta, V. (2000). Obecná biologie pro gymnázia. 3. přepracované vydání. Praha: Fortuna.

Kvasničková, D. (2013). Základy biologie a ekologie. 4. přepracované vydání. Praha: Fortuna.

Novotný, I., \& Hruška, M. (2015). Biologie člověka pro gymnázia. 5. upravené a rozšǐřené vydání. Praha: Fortuna. 
Odstrčil, J., \& Hrůza, A. (2016). Biologie pro zdravotnické školy. Brno: NCO NZO.

Papáček, M., Matěnová, V., Matěna, J., \& Soldán, T. (2000). Zoologie. 3. vydání. Praha: Scientia.

Rosypal, S., Doškař, J., Frynta, D., Homola, J., Horáček, I., Hůrka, K., Kalina, T., Kubišta, V., Kvaček, Z., Linc, R., Losos, B., Mazura, I., Mladá, J., Mladý, F., Nedvídek, J., Novotný, I., Pavlová, L., Pikálek, P., Prášil, K., Psota, V., Roček, Z., Slavíková, J., Slavíková, Z., Smrž, J., Šašek, V., Šebánek, J., Šmarda, J., Štys, P., \& Zrzavý, J. (2003). Nový přehled biologie. Praha: Scientia.

Smrž, J., Horáček, I., \& Śvátora, M. (2004). Biologie živočichů pro gymnázia. 1. vydání. Praha: Fortuna.

Šlégl, J., Kisinger, F., \& Laníková, J. (2002). Ekologie a ochrana životního prostředí pro gymnázia. Praha: Fortuna.

Šmarda, J. (2003). Genetika pro gymnázia. Praha: Fortuna.

Závodská, R. (2006). Biologie buněk: základy cytologie, bakteriologie, virologie. Edice Biologie pro gymnázia. Praha: Scientia. 